\title{
Building Consumers' Trust Based on Pick-up Goods Behavior in the Convenience Stores in Taiwan
}

\author{
Chun-Chia Wang \\ Department of Information Management \\ Taipei Chengshih University of Science and Technology \\ Beitou, Taipei, Taiwan 112 \\ toshihitowang@gmail.com
}

\begin{abstract}
With the adoption of Internet, online shopping has provided a convenience way to purchase goods or services from anywhere at any time in recent years globally. Especially, convenience stores are available for consumers to pick up goods ordered from Internet shops in Taiwan. Therefore, convenience stores have become an important success factor for increasing a lot of profit in online shopping in Taiwan.

In the past, researches have indicated that consumers dare not or are not willing to purchase goods in online shopping. The reasons include the problem of security and the lack of consumers' trust. Thus, these problems constitute a key barrier to the use of online shopping as well as long-term commitment to the relationship building. Therefore, there is a need to build up consumers' trust in order to overcome the influential factors in online shopping. In this paper, we use statistic analysis method by questionnaires to discuss the characteristics of pick-up goods in the convenience stores and illustrate the relationship between consumers' trust in online shopping and pick-up goods behavior in convenience stores. In our experiment, questionnaire items are measured by Likert scale. In 227 valid questionnaires, $90 \%$ participants deeply believe that pick-up goods in the convenience stores can promote consumers' trust in online shopping.
\end{abstract}

Index Terms-Consumers' Trust, Online Shopping, Convenience Stores, Likert Scale

\section{Introduction}

The number of Internet users has increased exponentially in Taiwan. According to the statistical date from Foreseeing Innovative New Digiservices (FIND) ${ }^{[9]}$, there were 10.79 million internet users in Taiwan, which comprised $47 \%$ of the Taiwan population. From the survey of Taiwan Network Information Center ${ }^{[10]}, 52.7 \%$ of Internet users were using Internet for searching information, $31.39 \%$ were checking weather forecast, $28.9 \%$ were subscribing information, and $19.6 \%$ were making online shopping. According to Market Intelligence \& Consulting Institute (MIC) ${ }^{[11]}$, the trading of online shopping in Taiwan in 2011 has reached to 430 billion NT dollars, which is $20.01 \%$ growth than last year. The main reasons why online shopping increased are as follows: the traditional enterprises reach their market to e-commerce, e-commerce expanded into multi-purposes, cross-national online shopping, and the extreme of internet marketplace.

Although the market of Internet shopping in Taiwan has increased, there are lots of consumers who dare not or are not willing to purchase in online shopping. According to MIC and InsightXplorer ${ }^{[12]}$, as their surveys of Taiwan Internet shopping market, the reasons why consumers like or don't like online shopping are as follows.

Reasons why consumers like online shopping are as follows:

1. Cheap: online shopping and audition have cut down a lot of costs from manpower and transition. And in return, the price can be very cheap. From the consumers' point of view, if they don't have to go out for shopping, they can save a lot of money from transportation. For bargain-picking consumers, online shopping is the best choice.

2. Convenient: there are no limits on time and places for online shopping. Also a smart consumer can search all the relative products via internet and review the comments of other internet consumers. Even more, they can find foreign products without boundaries. Besides, you don't have to go out and the products will be delivered to your places. Thus, for those who don't have time to go shopping and don't want to go out for shopping, online shopping is more convenient and attractive.

3. On sale and gift: instead of cheap, online shopping is getting more attractive with on-sale promotion and giving gifts.

4. Shopping with no burden: most consumers don't like aggressive salesmen and are afraid of buying inappropriate products. Online shopping can get rid of these troubles.

Reasons why consumers don't like online shopping are as follows.

1. Afraid of Internet fraud and the security of internet trading: according to the survey of InsightXplore, the reasons why consumers don't use online shopping because $43 \%$ of consumers don't trust Internet shopping. There are 52\% Internet shoppers choosing to pay by cash. The purchase behavior revealed that most consumers still don't trust Internet shopping system. Barriers 
to online shopping include the loss of privacy of personal data and discomfort with seller anonymity.

2. Difficulty in assessment of product: Consumers with experiential orientation (need to examine merchandise physically before purchasing) experience high product uncertainty with online stores because they are unable to examine online products before purchasing. They prefer to compare, touch and test goods in real stores. This situation is not suitable to apply to online shopping since consumers cannot assess products directly and cannot get products immediately.

3. Difficulty of returning and exchanging products: Consumers are worried about false claims by online stores as well as poor after-sales service. This increases transaction cost as consumers spend more time searching for suitable stores and monitoring their transactions.

4. Lack of faith between online stores and consumers has prevented people from shopping: most shopping websites (especially the big ones) have to sign in before shopping or need to have membership to buy some special products. Instead of cash on delivery and credit card payment, some online stores (especially auction private sellers) asked buyers to pay first. After buyers showed their ATM transition, sellers delivered products. The process of trading prevented consumers from online shopping.

As we know, there are many previous researches in the field of trust issue in online shopping. However, consumers' trust in online shopping is much complicated than the traditional type of trading, which includes the security of electronic trading for taking into consideration. [3] stated that there is no 'best' or 'safest' way of electronic payment system. Interestingly, in recent years, convenience stores in Taiwan have integrated ecommerce with the logistics system of convenience stores to build a new retail delivery model. By "Online shopping in Internet store and pick-up goods in the convenience store" system, consumers feel more comfortable about unsecured problem in online shopping. Therefore, the key contribution of this paper is to propose a moderation effect on the consumers' trust in online shopping. The main purposes of this paper are as follows.

1. To discuss the trust degree of online shopping in the system of 'online shopping in Internet store and pick-up goods in the convenience store'.

2. To illustrate main reasons of the promotion of trust degree in online shopping by 'pick-up goods in the convenience store'.

3. Are there any influent factors about trust degree in basic information, Internet experience and online shopping experience?

This paper is organized as follows. In section II, model of pick-up goods and influence factors that caused consumers' trust in online shopping is described. In section III, we develop our research method and the hypotheses of the research are proposed to explain the relationship between consumers' trust and pick-up goods in the convenience store. In section IV, we input statistical analysis from data collection to discuss our important findings and section $\mathrm{V}$, we make a summary conclusion and discussions of future research are issued.

\section{Related Work}

\subsection{The Characteristics of Online Shopping}

Online shopping behavior means buying products over the Internet. Therefore, the characteristics of online shopping are different from real product purchase. Bakos ${ }^{[1]}$ considered the market of online shopping can provide cheaper products and lower information cost. Therefore, consumers are more efficient to reach sellers who can meet their needs. There are three advantages of online shopping as follows.

1. Consumers can pay less to get products.

2. Consumers can have correct product information and make better purchase decision.

3. The cost of searching information is lower without wasting time to search.

Although online shopping has become popular in recent years, however, there are four disadvantages of online shopping as follows.

1. Fraud and security concerns: Given the lack of ability to inspect merchandise before purchase, consumers are at higher risk of fraud on the part of the merchant than in a traditional store. Merchants also risk fraudulent purchases using stolen credit cards or fraudulent repudiation of the online purchase.

2. Lack of full cost disclosure: The lack of full disclosure with regards to the total cost of purchase is one of the concerns of online shopping. While it may be easy to compare the base price of an item online, it may not be easy to see the total cost up front as additional fees such as shipping are often not be visible until the final step in the checkout process.

3. Privacy: Privacy of personal information is a significant issue for consumers. Different legal jurisdictions have different laws concerning consumer privacy, and different levels of enforcement. Many consumers wish to avoid spam and telemarketing which could result from supplying contact information to an online merchant.

4. Hands-on Inspection: Typically, only simple pictures and or descriptions of the item are all a customer can rely on when shopping on online stores. If the customer does not have prior exposure to the item's handling qualities, they will not have a full understanding of the item they are buying.

\subsection{The Model of Pick-Up Products in the Convenience Stores}

Convenience stores started their service of pick-up products for online shopping in 1999. The rise of ecommerce encouraged the birth of third party distribution. Under the contribution of Internet retailers, third party 
distribution and pick-up goods in the convenience stores become the most important model of e-commerce distribution in Taiwan.

$\mathrm{Wu}^{[8]}$ classified consumers pick up products for online shopping into two parts: one is passive receiving; the other is active receiving. Passive receiving included post delivery, express delivery, hand delivery, cargo delivery and home delivery, etc. By speed and cost, there are two ways of delivery. One is common post delivery, the other is hand delivery. The characteristics of delivery and receiving products are shown in Table 1 . Common post delivery includes post delivery and cargo delivery, etc. The characteristics of common post delivery are cheap but slow. Hand delivery includes express delivery and home delivery which are more expensive and fast than post delivery. There are two ways of active receiving: one is pick-up in delivery points; the other is pick-up in convenience stores. The differences are convenience stores are everywhere and opened 24 hours but the advantages of delivery points are the precise and complete of products.

\begin{tabular}{|c|c|c|c|c|}
\hline \multicolumn{7}{|c|}{ Table 1: The Comparison of Distribution } \\
\hline & $\begin{array}{c}\text { Common post } \\
\text { delivery }\end{array}$ & $\begin{array}{c}\text { Hand } \\
\text { delivery }\end{array}$ & $\begin{array}{c}\text { Delivery } \\
\text { points }\end{array}$ & $\begin{array}{c}\text { Convenience } \\
\text { stores }\end{array}$ \\
\hline $\begin{array}{c}\text { Efficiency } \\
\text { (speed of delivery) }\end{array}$ & slow & fast & middle & middle \\
\hline $\begin{array}{c}\text { cost } \\
\text { cost of delivery }\end{array}$ & low & high & none & none \\
\hline $\begin{array}{c}\text { Places } \\
\text { Places of receiving }\end{array}$ & common & common & special & special \\
\hline $\begin{array}{c}\text { Accuracy } \\
\text { Time \& products }\end{array}$ & low & high & high & middle \\
\hline
\end{tabular}

Delivery and returning goods is a daily works for convenience stores. To join the logistics operations modeling carried out in store delivery of convenience stores, variable cost can be cut down to the lowest ${ }^{[4]}$. The characteristics of daily delivery, on time, and tracking system of goods make the logistics operations modeling carried out in store delivery of convenience stores as shown in Figure 1.

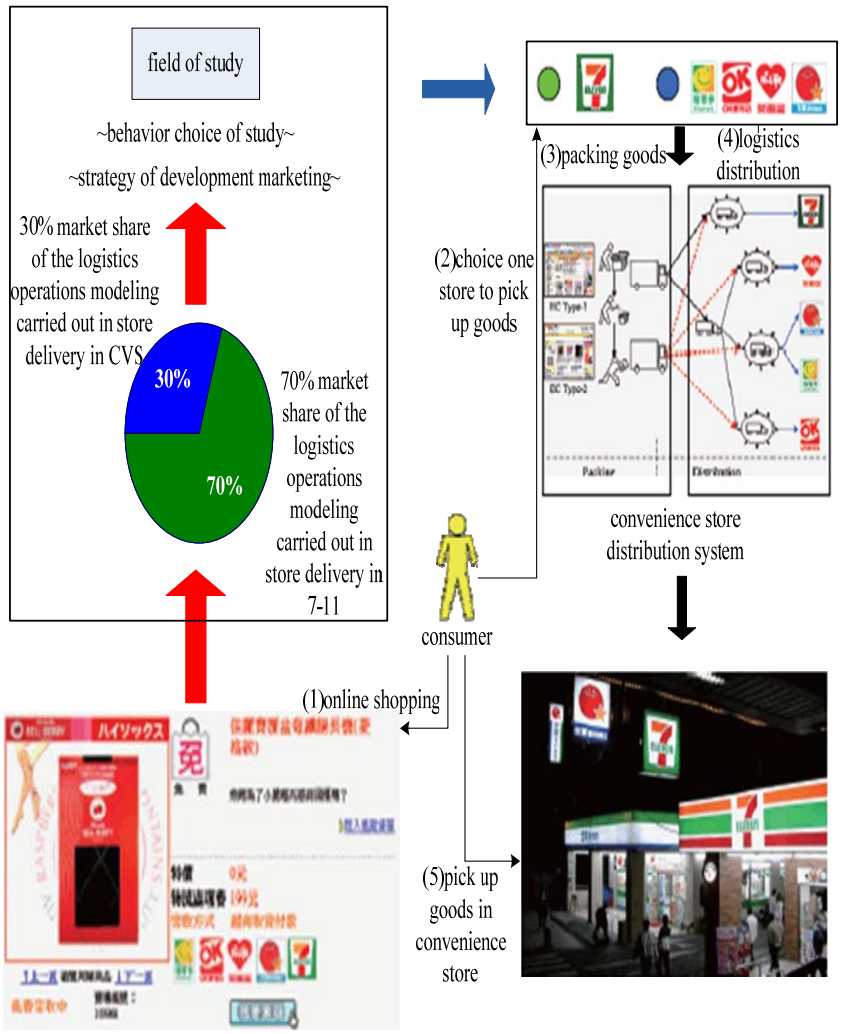

Fig 1: Structure of the Logistics Operations Modeling Carried Out in Store Delivery ${ }^{[4]}$

\subsection{The Consumers' Trust in Online Shopping}

Trust is based on psychology. Many researchers provided different definition of trust, but few of them mentioned trust of online shopping. In the past, many researchers tried to discuss why e-commerce cannot replace retailers. One of the reason is online retailers face a situation in which consumer trust might be expected to be inherently low ${ }^{[6,7]}$. Sonja ${ }^{[6]}$ considered trust is not a short-term problem, but long-term barriers for online shopping. Because there are lots of risks on the process of Internet transition, the main risks of online shopping can be classified into two catalogues: one is product risk; the other is security risk. Product risk means consumers cannot evaluate products via Internet. Security risk means consumers worried about personal data would reveal though open internet transition ${ }^{[2]}$. The main reason why consumers didn't go online shopping is short of trust.

Lee and Turban ${ }^{[5]}$ identified Consumer Trust in Internet Shopping (CTIS) as "On the process of online shopping, consumers' willingness to buy online is low. No matter if or if not consumers have ability to monitor or track Internet retailers, they predicted retailers would enact the behavior of Internet exchange." Thus, they provided consumers' trust model in online shopping as shown in Figure 2. 


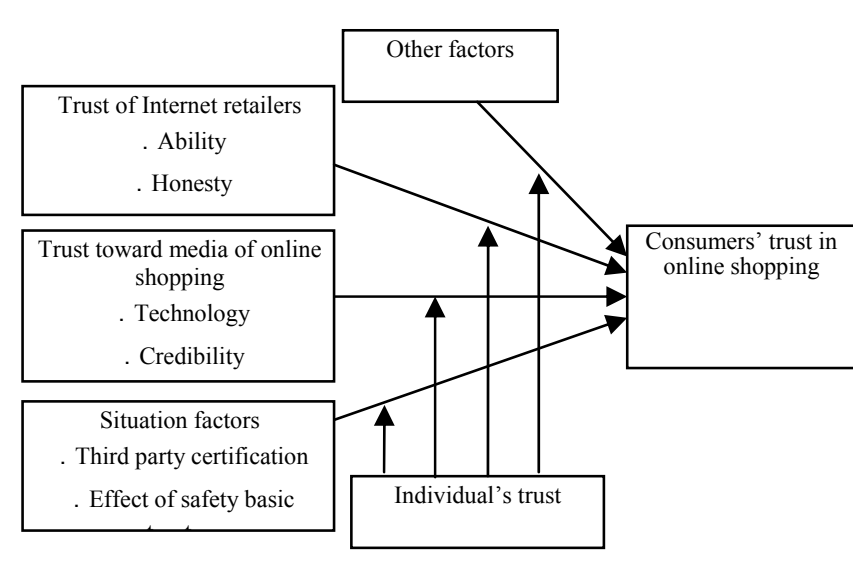

Fig 2: Consumers' Trust in Online Shopping ${ }^{[5]}$

According to related work, trust is the main reason why consumers are not willing to go online shopping. Also, to pick up goods in convenience stores is much safe and convenient than online shopping. This paper is to discuss if there is any influence for consumers' trust in online shopping to pick up goods in convenience stores.

\section{Research model and hypotheses}

To realize the influence for online shoppers' trust to pick up goods in convenience stores, the major research participants focus on online shopping consumers. Through questionnaire and related work, this paper tries to find out the characteristics of pick-up goods in convenience stores. Questions include four factors: demographic factor, experience of internet usage, experience of online shopping and trust of pick-up goods in convenience stores. The trust model of this paper is shown in Figure 3. According to the model, there are three hypotheses and give an explanation below.

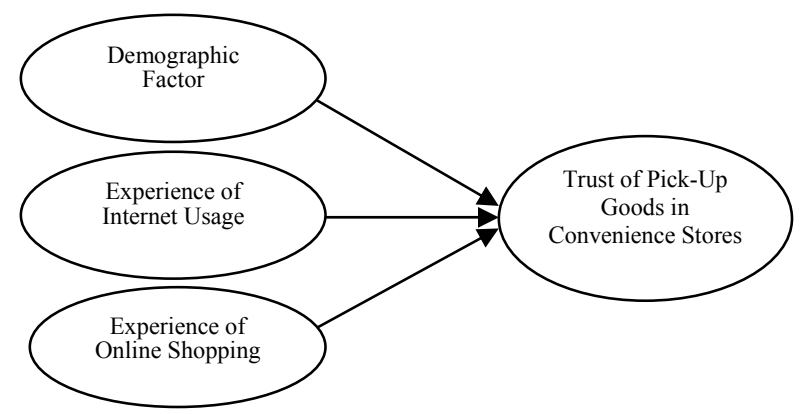

Fig 3: The Three Influence Factors of Consumers' Trust of Pick-Up Goods in Convenience Stores

\subsection{Design of Questionnaire}

The questionnaire is processing based on related work and all related questions. The content of questionnaire includes four parts: subjects' personal data, experience of Internet usage-to investigate subjects' behavior of Internet usage and habits, experience of online shoppingto realize subjects' experience of Internet usage, the ways of payment and pick-up goods, and finally the influence of trust of online shoppers toward pick-up goods in convenience stores. We adopt Likert scale to measure the variances of service characteristics of pick-up goods in convenience stores. Fifteen items used a five point response format, from $1=$ strongly disagree to $5=$ strongly agree.

\subsection{Test}

To assure the subjects can fully understand the content of questionnaire and to avoid questions were not answered properly, before delivering the questionnaire we asked scholars to assure the accuracy of the questionnaire. Besides, we collected 20 tests on Internet. Learning from test participants provided by their opinions, we adjusted the content of questionnaire after discussion with scholars

\subsection{Credibility of Analyzing the Questionnaires}

Analysis of credibility is to measure the accuracy of questionnaire. The measuring results showed the credibility, consistence and stability of the questionnaire. In Likert scale, when Cronbach's $\alpha$ is higher than 0.7 , it represents higher credibility and the questionnaire is more reliable. By using Cronbach's $\alpha$ to measure the credibility of questionnaire, it showed the average of Cronbach's $\alpha$ was higher than 0.8 which meant the questionnaire is higher reliable and consistent.

\subsection{Hypotheses}

According to variables of research structure, we created the following hypotheses. Previous researches took characteristics of people as one of the variables of influence, thus the hypotheses of the research are as follows:

H1: Different cohort of consumers makes a great impact on how the pick-up services in convenience store affects consumers' trust in online shopping.

H1-1: Different sex of consumers makes a great impact on how the pick-up service in convenience store affects consumers' trust in online shopping.

H1-2: Different age of consumers makes a great impact on how the pick-up service in convenience store affects consumers' trust in online shopping.

H1-3: Different status of marriage of consumers makes a great impact on how the pick-up service in convenience store affects consumers' trust in online shopping.

H1-4: Different education of consumers makes a great impact on how the pick-up service in convenience store affects consumers' trust in online shopping.

H1-5: Different resident areas of consumers makes a great impact on how the pick-up service in convenience store affects consumers' trust in online shopping.

H1-6: Different occupation of consumers makes a great impact on how the pick-up service in 
convenience store affects consumers' trust in online shopping.

H1-7: Different monthly income of consumers makes a great impact on how the pick-up service in convenience store affects consumers' trust in online shopping.

H1-8: Whether the consumers have credit card makes a great impact on how the pick-up service in convenience store affects consumers' trust in online shopping.

H2: Customer's trust model in online shopping based on pick-up in the convenience stores differs very much among Internet users with different browsing experience.

H2-1: Customer's Trust Model of Online Shopping Based on Pick-up at Convenience Store differs very much with different Internet browsing experience.

H2-2: Customer's Trust Model of Online Shopping Based on Pick-up at Convenience Store differs very much among internet users with different online frequency.

H2-3: Customer's Trust Model of Online Shopping Based on Pick-up at Convenience Store differs very much among internet users with different browsing time.

H2-4: Customer's Trust Model of Online Shopping Based on Pick-up at Convenience Store differs very much among internet users with most often online places.

Because the research is to discuss consumers' trust model in online shopping, so Internet users' browsing experience makes a impact on trust model in online shoppers. The hypotheses are as follows:

H3: Consumers with different Internet shopping experience make an impact on trust model in online shopping.

H3-1: Whether the consumers have the experience of picking up goods in convenience store makes a great impact on trust model in online shopping.

H3-2: Whether the consumers have the experience of picking up goods in convenience store in past 6 months makes a great impact on trust model in online shopping.

H3-3: How much do the consumers cost monthly of picking up goods in convenience store makes a great impact on trust of model in online shopping.

H3-4: Whether the consumers have the experience of picking up goods in convenience stores makes a great impact on how the pick-up services in convenience store affects consumers' trust in online shopping.

H3-5 : Most frequent paying way of picking up goods in convenience store makes a great impact on how the pick-up service in convenience store affects consumers' trust in online shopping.

H3-6: Main receiving way of picking up goods in convenience store makes a great impact on how the pick-up service in convenience store affects consumers' trust in online shopping.

\section{Data Analysis \\ 4.1 Data Collection}

From Feb. to March in 2011, the paper started by delivery questionnaire through Internet and paper forms. We had 230 pieces back and three of them were invalid, so there were 227 valid questionnaires.

Most of the participants aged from 21-29 (42.29\%), educated to colleges $(46.7 \%)$, lived in the northern part of Taiwan (81.94\%), frequent online place was at home (72.25\%), had online shopping experience (81.94\%), had pick up goods in convenience store experience (63.44\%), paid in convenience store for delivery $(46.77 \%)$, paid by credit online came to the second $(27.42 \%)$, main receiving method was in convenience store (47.31\%), home delivery came to the second (39.25\%).

\subsection{Influence of Consumers' Trust in Online Shopping Based on Pick-Up Goods in the Convenience Stores}

In 227 valid questionnaires, most participants considered picking-up goods in convenience store could promote consumers' trust model in online shopping. The average points fall on over 4 but not up to $5(68.28 \%)$ and points over 3 but not up to $4(30.84 \%)$. It is shown in Figure 4.

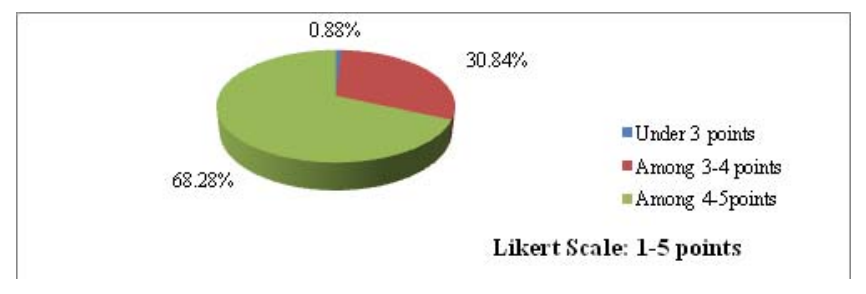

Fig 4: Average Points of Consumers' Trust in Online Shopping Based on Pick-Up Goods in the Convenience Stores

According to Figure 4, about $90 \%$ participants whose points over three sensed pick-up goods in convenience stores promote consumer's trust in online shopping. The participants whose points fall on over 4 (68.28\%) sensed pick-up goods in convenience store could promote consumers' trust model in online shopping. Thus, the average points was 4.26 points. The figure shows an influential result that the behavior of pick-up goods in 
convenience store promotes consumers' trust in online shopping. It is shown in Table 2.

Table 2: Consumers' Trust in Online Shopping Based on Pick-Up Goods in Convenience Stores

\begin{tabular}{|l|l|}
\hline $\begin{array}{l}\text { Reasons why consumer choose to pick up goods in } \\
\text { convenience store }\end{array}$ & $\begin{array}{l}\text { Average } \\
\text { point }\end{array}$ \\
\hline 24-hour receiving service & 4.52 \\
\hline $\begin{array}{l}\text { There are seven days for consumers to pick up goods after } \\
\text { their order arrived in convenience store }\end{array}$ & 4.30 \\
\hline Delivery cost is low & 3.91 \\
\hline Easy to reach convenience store & 4.51 \\
\hline Convenience store is near & 4.47 \\
\hline Text message to notice the arriving of goods & 4.42 \\
\hline Email to notice the arriving of goods & 4.07 \\
\hline Assistance from employees in convenience store at anytime & 4.04 \\
\hline Track the information of goods via internet or phone & 4.30 \\
\hline Return policy in convenience store & 4.18 \\
\hline Avoid face-face trading problems & 4.04 \\
\hline Assure personal privacy without filling phone and address & 4.30 \\
\hline $\begin{array}{l}\text { Pick up personal orders in convenience store to protect } \\
\text { privacy }\end{array}$ & 4.17 \\
\hline Pay by cash avoid the insecure of using credit card online & 4.25 \\
\hline Decrease the risks of using credit card and ATM & 4.37 \\
\hline Average & 4.26 \\
\hline
\end{tabular}

\subsection{Analysis of Research}

This paper listed 15 questions of pick-up goods in convenience store. Through analysis of research, we adjusted factors. There are three factors in this paper: service, convenience and safety. Among the three factors, convenience is the highest (4.38 points); safety comes to the second (4.27 points); service comes to the third (4.09 points). The average points are over 4 points. It shows those factors make an impact on consumers' trust model in online shopping. It is shown in Table 3.

Table 3: Factors Made an Impact on Consumers' Trust Model in Online Shopping

\begin{tabular}{|c|c|c|c|}
\hline factors & content & Cronbach's $\alpha$ & average \\
\hline \multirow{5}{*}{ service } & $\begin{array}{l}\text { Assistance from employees in convenience store at } \\
\text { anvtime }\end{array}$ & \multirow{5}{*}{0.842} & \multirow{5}{*}{4.09} \\
\hline & Return policy in convenience store & & \\
\hline & $\begin{array}{l}\text { Track the information of goods via internet or } \\
\text { phone }\end{array}$ & & \\
\hline & Avoid face-face trading problems & & \\
\hline & delivery cost is low & & \\
\hline \multirow{6}{*}{ convenience } & easy to reach convenience store & \multirow{6}{*}{0.822} & \multirow{6}{*}{4.38} \\
\hline & 24-hour receiving service & & \\
\hline & convenience store is near & & \\
\hline & $\begin{array}{l}\text { There are seven days for consumers to pick up } \\
\text { goods after their order arrived in convenience store }\end{array}$ & & \\
\hline & text mess age to notice the arriving of goods & & \\
\hline & Email to notice the arriving of goods & & \\
\hline \multirow{4}{*}{ safety } & $\begin{array}{l}\text { Pay by cash avoid the insecure of using credit card } \\
\text { online }\end{array}$ & \multirow{4}{*}{0.855} & \multirow{4}{*}{4.27} \\
\hline & $\begin{array}{l}\text { Pay by cash avoid the insecure of using credit card } \\
\text { online }\end{array}$ & & \\
\hline & $\begin{array}{l}\text { Pick up personal orders in convenience store to } \\
\text { protect privacy }\end{array}$ & & \\
\hline & $\begin{array}{l}\text { Assure personal privacy without filling phone and } \\
\text { address }\end{array}$ & & \\
\hline
\end{tabular}

\subsection{Analysis of Variance}

Furthermore, after analyzing factors, we process analysis of variance through demography, Internet browsing experience and online shopping experience. In demography variance, status of marriage and monthly income didn't reach 5\%, so don't take into consideration. Only participants' education made impact on service and safety. Participants who had college degrees consider service is important to consumers' trust in online shopping. It is shown in Table 4.
Table 4: Analysis of Demography Variance of Pick- Up Goods in Convenience Store

\begin{tabular}{|c|c|c|c|c|c|c|c|c|}
\hline variance & sex & age & $\begin{array}{c}\text { Marriage } \\
\text { status }\end{array}$ & education & $\begin{array}{c}\text { Resident } \\
\text { area }\end{array}$ & occupation & $\begin{array}{c}\text { Monthly } \\
\text { income }\end{array}$ & $\begin{array}{c}\text { Credit } \\
\text { card }\end{array}$ \\
\hline service & -0.643 & 1.369 & $4.699^{* *}$ & $4.880^{* *}$ & 0.105 & 1.621 & $2.408^{*}$ & -1.704 \\
\hline Convenience & -1.320 & 1.263 & 1.087 & 1.218 & 0.250 & 1.030 & 1.047 & -1.137 \\
\hline safety & -1.238 & 0.697 & 1.500 & $3.894^{*}$ & 0.315 & $2.000^{*}$ & $3.282^{* *}$ & -1.777 \\
\hline
\end{tabular}

In analysis of variance, pick-up goods in convenience store don't make any impact on service, convenience and safety in Internet browsing experience. No matter the experience of Internet browsing is high or low, it doesn't make any impact on consumers' trust model. The reason might be trust putted in a very early process of development in personality ${ }^{[7]}$.

The analysis of variance of pick-up goods of online shopping experience in convenience stores, pick-up goods in convenience store and the way of receiving would make an impact on convenience. Those who had experience to pick-up goods in convenience stores (4.47 points) consider convenience had higher impact on consumer's trust model of online shopping than those who didn't have experience (4.17 points). The ways of receiving: convenience stores (4.49 points) and home delivery (4.39 points) were higher than others (3.61 points). However, others was lower than $5 \%$ so not taking into consideration. It is shown in Table 5.

Table 5: $\mathrm{t} / \mathrm{F}$ Values of Analysis of Variance: The Experience of Pick-Up Goods in Convenience Stores

\begin{tabular}{|c|c|c|c|c|c|c|}
\hline factors & experience & times & amount & $\begin{array}{c}\text { Experience } \\
\text { of pick up } \\
\text { goods in } \\
\text { store }\end{array}$ & $\begin{array}{c}\text { Way of } \\
\text { payment }\end{array}$ & $\begin{array}{c}\text { Way of } \\
\text { recieving }\end{array}$ \\
\hline service & -1.509 & 1.337 & 1.661 & -0.263 & 0.522 & 1.813 \\
\hline convenience & 1.277 & 1.577 & 1.515 & $-3.016 *$ & 1.158 & $3.168^{*}$ \\
\hline safety & 0.026 & 0.781 & 1.103 & 1.919 & 1.347 & 2.061 \\
\hline
\end{tabular}

Whether consumers had experience of pick up goods in convenience stores made an impact on consumers' trust. The reason might be consumers who had experience of pick-up goods in convenience stores realize the convenience of the service and promote trust.

The education degrees show an impact on consumers' trust. The reason might be consumers who had lower education degrees are easy to trust others. Otherwise, those who had higher education are hard to trust others.

\subsection{Check of Hypotheses}

Hypotheses of the research were consumer's trust model in online shopping toward pick-up goods in convenience stores. After checking these three hypotheses, the results are shown in Table 6, 7, 8, 9, respectively. 
Table 6: Factors of Demography Made an Impact on Online Shopping

\begin{tabular}{|l|c|}
\hline \multicolumn{1}{|c|}{ hypotheses } & Yes or no \\
\hline $\begin{array}{l}\text { H1-1: Different sex of consumers makes a great impact on how the } \\
\text { pick-up service in convenience store affects consumers' trust in online } \\
\text { shopping. }\end{array}$ & No \\
\hline $\begin{array}{l}\text { H1-2: Different age of consumers makes a great impact on how the } \\
\text { pick-up service in convenience store affects consumers' trust in online } \\
\text { shopping. }\end{array}$ & No \\
\hline $\begin{array}{l}\text { H1-3: Different status of marriage of consumers makes a great impact } \\
\text { on how the pick-up service in convenience store affects consumers' } \\
\text { trust in online shopping }\end{array}$ & Yes \\
\hline $\begin{array}{l}\text { H1-4: Different education of consumers makes a great impact on how } \\
\text { the pick-up service in convenience store affects consumers' trust in } \\
\text { online shopping. }\end{array}$ & Yes \\
\hline $\begin{array}{l}\text { H1-5: Different resident areas of consumers makes a great impact on } \\
\text { how the pick-up service in convenience store affects consumers' trust } \\
\text { in online shopping }\end{array}$ & No \\
\hline $\begin{array}{l}\text { H1-6: Different occupation of consumers makes a great impact on } \\
\text { how the pick-up service in convenience store affects consumers' trust } \\
\text { in online shopping }\end{array}$ & No \\
\hline $\begin{array}{l}\text { H1-7 : Different monthly income of consumers makes a great impact } \\
\text { on how the pick-up service in convenience store affects consumers' } \\
\text { trust in online shopping. }\end{array}$ & No \\
\hline $\begin{array}{l}\text { H1-8: Whether the consumers have credit card makes a great impact } \\
\text { on how the pick-up service in convenience store affects consumers' } \\
\text { trust in online shopping. }\end{array}$ & No \\
\hline
\end{tabular}

Table 7: Hypotheses of Internet Browsing Experience on Consumers' Trust Model in Online Shopping

\begin{tabular}{|c|c|}
\hline hypotheses & Yes or No \\
\hline $\begin{array}{l}\text { H2-1 : Customer's Trust Model of Online Shopping Based on Pick-up at } \\
\text { Convenience Store differs very much among internet users with } \\
\text { different browsing experience }\end{array}$ & No \\
\hline $\begin{array}{l}\text { H2-2: Customer's Trust Model of Online Shopping Based on Pick-up at } \\
\text { Convenience Store differs very much with different Internet browsing } \\
\text { experience. }\end{array}$ & NO \\
\hline $\begin{array}{l}\text { H2-3 : Customer's Trust Model of Online Shopping Based on Pick-up at } \\
\text { Convenience Store differs very much among internet users with } \\
\text { different browsing time. }\end{array}$ & NO \\
\hline $\begin{array}{l}\text { H2-4 : Customer's Trust Model of Online Shopping Based on Pick-up at } \\
\text { Convenience Store differs very much among internet users with most } \\
\text { often online places. }\end{array}$ & NO \\
\hline
\end{tabular}

Table 8: Hypotheses of Internet Shopping Experience on Consumers' Trust Model in Online Shopping

\begin{tabular}{|l|c|}
\hline \multicolumn{1}{|c|}{ hypotheses } & Yes or No \\
\hline $\begin{array}{l}\mathrm{H} 3-1: \text { Whether the consumers have the experience of picking up goods in } \\
\text { convenience store makes a great impact on trust model of online shopping. }\end{array}$ & No \\
\hline $\begin{array}{l}\mathrm{H} 3-2: \text { Whether the consumers have the experience of picking up goods in } \\
\text { convenience store in past } 6 \text { months makes a great impact on trust model of } \\
\text { online shopping. }\end{array}$ & No \\
\hline $\begin{array}{l}\text { H3-3: How much do the consumers cost monthly of picking up goods in } \\
\text { convenience storemakes a great impact on trust of model of online shopping. }\end{array}$ & No \\
\hline $\begin{array}{l}\text { H3-4: Whether the consumers have the experience of picking up goods in } \\
\text { convenience store makes a great impact on how the pick-up service in } \\
\text { convenience storeaffects consumers' trust in online shopping. }\end{array}$ & Yes \\
\hline $\begin{array}{l}\text { H3-5: Most frequent paying way of picking up goods in convenience store } \\
\text { makes a great impact on how the pick-up service in convenience store affects } \\
\text { consumers' trust in online shopping. }\end{array}$ & No \\
\hline $\begin{array}{l}\text { H3-6: Main receiving way of picking up goods in convenience store makes a } \\
\text { great impact on how the pick-up service in convenience store affects } \\
\text { consumers' trust in online shopping. }\end{array}$ & No \\
\hline
\end{tabular}

Table 9: The Overall Results of Three Hypotheses

\begin{tabular}{|c|c|}
\hline hypotheses & Yes or no \\
\hline $\begin{array}{l}\mathrm{Hl} \text { : Different cohort of consumers makes a a great impact on how } \\
\text { the pick-up service in convenience store affects consumers' trust in } \\
\text { online shopping }\end{array}$ & Partly yes \\
\hline $\begin{array}{l}\text { H2 : Customer's Trust Model of Online Shopping Based on Pick-up at } \\
\text { Convenience Store differs very much among internet users with } \\
\text { different browsing experience }\end{array}$ & No \\
\hline $\begin{array}{l}\text { H3 : Consumers with different internet browsing experience make a } \\
\text { impact on trust model of online shopping. }\end{array}$ & Partly yes \\
\hline
\end{tabular}

In H1: Different cohort of consumers makes a great impact on how the pick-up services in convenience store affects consumers' trust in online shopping. The factors are sex, age, status of marriage, degree of education, resident areas, occupation, monthly income and credit cards. In all the factors, only degree of education s makes a great impact on how the pick-up service in convenience store affects consumers' trust in online shopping. People who graduated from college consider service promoting consumers' trust in online shopping. However, people who graduated from high school consider security promoting consumers' trust in online shopping. Thus, H1 is partly 'Yes'.

In H2, Customer's trust model in online shopping based on pick-up in the convenience stores differs very much among Internet users with different browsing experience. The factors are : different Internet browsing experience, different online frequency and most often online places. All the factors didn't have an impact. Thus, H2 is 'No'.

In H3, Consumers with different Internet shopping experience make an impact on consumers' trust model in online shopping. The experience are: picking up goods in convenience store, picking up goods in convenience store 
in past 6 months, average cost of online shopping, pickup service in convenience store and receiving way. All the factors, only whether the consumer had experience pick-up goods in convenience store made a great impact. Thus, H3 is partly 'Yes'.

\section{Conclusions}

The main contribution of this paper is to investigate consumers' trust in online shopping based on pick-up goods in the convenience stores in Taiwan. Our experimental results show that firstly, two of the three hypotheses support the relationship between pick-up goods behavior in the convenience stores and consumers' trust. Secondly, in the results of statistic analysis receiving from 227 valid questionnaires, this paper shows that pick-up goods in the convenience stores is one of important factors that contribute to consumers' trust in Taiwan. Finally, this paper makes a valuable contribution not only to the information online shop managers needed but also the overall body of consumers' trust and diffusion research. The influence factors of pick-up goods in the convenience stores to consumers' trust concluded as follows:

1. Pick-up goods in convenience stores can promote consumers' trust in online shopping. By review and analysis of data, the average point of trust is over 3 $(87.23 \%)$. It shows that $90 \%$ of the participants considered pick-up goods in convenience stores could promote consumers' trust model in online shopping.

2. The characteristics of pick-up goods in convenience stores. By analysis of factors, we conclude three characteristics of pick-up goods in convenience stores: service, convenience, and safety. Convenience is the highest with 4.38 points; safety comes to the second with 4.27 points, finally service has 4.09 points. It showed convenience is the most important factor.

3. There are three major advantages of pick-up goods in convenience stores. 24-hour service is the best ( 4.52 points), free to choose receiving time can promote consumers' trust model in online shopping; easy to reach convenience stores (4.51 points) and convenience store is near (4.447 points) show easy of receiving can promote consumers' trust model in online shopping; delivery cost is low (3.91 points) makes a small part of impact.

4. Degrees of education make an impact on consumers' trust model in online shopping.

5. Whether the consumer had experience of pick-up goods in convenience store make an impact on consumers' trust model in online shopping. The one who had experience of pick-up goods in convenience store considered convenience is the key point of higher trust in online shopping.

According to our important findings, it will be useful for traders who would like to increase consumers' trust in online shopping. They are inclined to decrease the risk for consideration for the model of pick-up goods in the convenience stores. The future research is needed to progress towards more understanding factors that influence Internet business income based on this paper as follows:

1. Add consumer's satisfaction and loyalty: the research only focused on analysis of pick-up goods in convenience store toward consumers' trust model in online shopping. There are space for consumers' satisfaction and loyalty to survey.

2. Increase samples and make different groups of area and age: the research didn't take many samples and the research area focused on the northern part of Taiwan. There are still margins for increasing samples, creating groups: such as differ from teenage, young people, middle-age and old people, or make a comparison between urban and suburb areas, for making a more complete analysis.

\section{References}

[1] Bakos J. Y., "Reducing Buyer Search Costs: Implications for Electronic Marketplaces," Management Science, 1997, 43(12), pp. 1676-1692.

[2] Bhatnagar A. and Ghose S., "A Latent Class Segmentation Analysis of E-Shoppers," Journal of Business Research, 2002, 57, pp. 758-767.

[3] Draxler G., Sametinger J., Wiesauer A., "Electronic Payment and Online Gaming," Proceedings of the 16th International Conference on Distributed Multimedia Systems, October 14-16, Oak Brook, USA, 2010.

[4] Feng, C.M. and Huang Y.K., "The Effects of Switching Costs and Service Quality on Choice Behavior of the Pick-up Point for Online Shopping," Transportation Planning Journal Quarterly, 2006, 35(4), pp. 507-542.

[5] Lee, K.O. and Turban, E., "A Trust Model for Consumer Internet Shopping," International Journal of Electronic Commerce, 2001, 6(1), pp. 75-91.

[6] Sonja Grabner-Kraeuter, "The Role of Consumers' Trust in Online-Shopping," Journal of Business Ethics, 2002, 39(1/2), pp. 43-50.

[7] Visser E-J. and Lanzendorf M., "Mobility and Accessibility of B2C E-Commerce: A Literature Review," Tijdschrift voor Economische en Sociale Geografie, 2004, 95(2), pp. 189-205.

[8] Wu Chao-Le, "The Study of Consumers' Preference in Receiving Physical Goods on Internet shopping," Master Thesis, Tunghai University, Taichung, Taiwan, 2001.

[9] Internet in Taiwan 2010, FIND (Foreseeing Innovative New Digiservices): http://www.find.org.tw/find/home.aspx?page $=$ ma ny\&id $=282$

[10] Taiwan Network Information Center 2010 (TWNIC): http://statistics.twnic.net.tw/item04.htm

[11] Market Intelligence \& Consulting Institute (MIC) 2010: http://mic.iii.org.tw/aisp/pressroom/press01_pop.asp?sno $=225 \&$ type $1=2$

[12] InsightXplorer 2011: http://news.ixresearch.com/?p=921 
Chun-Chia Wang was born in 1966. He received his M.S. and Ph.D. degrees in Computer Science from TamKang University in 1994 and 1997, respectively. He is now an Associate Professor in Department of Information Management at Taipei Chengshih University of Science and Technology, Taipei, Taiwan. He has also been a Chairman of Department of Information Management at Taipei Chengshih University of Science and Technology for ten years. His research interests include cloud computing, software engineering, object-oriented technology, multimedia, and ecommerce. 